\title{
Violence AND the PRivate: A GiRARdian Model of DOMESTIC VIOLENCE IN SOCIETY
}

\author{
BRIAN R. DECKER

\section{INTRODUCTION}

Brett Myers punched his wife in the face. ${ }^{1}$ That's what the Philadelphia Phillies' ace pitcher's wife told police in June 2006. When the club was visiting Boston for interleague play, the couple was walking back to their hotel from a bar when they started arguing. ${ }^{2}$ Kim Myers said Brett, who is a foot taller than Kim and twice as heavy, "hit her in the face twice with his fist." According to witnesses, while Kim was cowering on the ground, Brett slapped her and attempted to drag her to her feet by her shirt and hair. "She cried out, "I'm not going to let you do this to me anymore." When police arrived, she was crying and her face was swollen. The district attorney arraigned Brett on assault and battery charges, ${ }^{6}$ but he was released and went on to start against the Red Sox the next day. ${ }^{7}$ Three months later, the court dismissed the case when Kim asked that the charges be dropped. ${ }^{8}$ Boston Municipal Court Judge Raymond Dougan reasoned that, "domestic violence allegations are difficult for prosecutors to prove because they involve private relationships." Brett expressed some semblance of regret, but not for the violence: "I'm sorry that it had to get public."10

The Myers domestic-violence case, though notable for its press coverage and the notoriety of its defendant, is not unusual. Statistics

\footnotetext{
${ }^{*}$ Brian R. Decker is an associate at Dechert LLP. AB Political Science and Religious Studies 2004, Stanford University; JD 2007, University of Pennsylvania Law School. Thanks to Bridget Crawford, Charlotte Fonrobert, and Carolyn Quam for their help with this article. Any errors are the author's alone.

${ }^{1}$ Suzanne Smalley, Visiting Player Hit Wife, Police Charge, Bos'on Globe, June 24, 2006, at B1.

${ }^{2} \mathrm{Id}$.

${ }^{3} I d$.

${ }^{4} I d$.

${ }^{5} I d$.

${ }^{6} I d$.

${ }^{7}$ Richard Justice, Caveman Era Never Ends in Baseball, Houston CHRON., June 27, 2006, Sports, at 1.

${ }^{8}$ April Simpson, Charge Against Pitcher Dismissed: Wife Asked that Court Drop Case Against Myers, Boston GLOBE, Oct. 6, 2006, at B1.

${ }^{9} I d$.

${ }^{10}$ Justice, supra note 7.
} 
identify women as the majority of victims of domestic violence, accounting for the victims of approximately 84 percent of incidents of domestic spousal violence. ${ }^{11}$ Of the 3.5 million incidents of violence against a family member in the United States each year, fewer than 60 percent are reported to police; ${ }^{12}$ fewer than 36 percent of those result in an arrest. ${ }^{13}$ Over 7 percent of those charged do not ultimately face adjudication, ${ }^{14}$ while fewer than half of those who do are convicted of a felony. ${ }^{15}$

America has a long history of treating domestic violence differently from public violence. ${ }^{16}$ From the nation's founding through the midnineteenth century, domestic violence jurisprudence was shaped by the common-law prerogative of chastisement, which allowed a husband to assault his wife within certain "reasonable" limitations. ${ }^{17}$ Though formal recognition of chastisement faded, twentieth-century jurisprudence nonetheless replaced it with justifications centered on the concept of privacy for avoiding enforcement of civil and criminal penalties in intramarital disputes. ${ }^{18}$ Despite the historical tendency of jurisprudence to employ mild, if any, punishment, recent statistics suggest that enforcement of criminal penalties against perpetrators of domestic violence may be on

11 BURLAU OI JUSTICL SIATISTICS, FAMILY VIOLLNCL STATISTICS INCLUDING STATISTICS ON STRANGERS AND ACQUAINTANCES 1 ("Females were $84 \%$ of spouse abuse victims and $86 \%$ of victims of abuse at the hands of a boyfriend or girlfriend [in 2005].").

${ }^{12} \mathrm{Id}$. at $22 \mathrm{tb} 1.4 .1$.

${ }^{13}$ Id. at 28 tbl. 4.7 .

${ }^{14}$ Compare id. at 45 tbl.6.1 (493 defendants in family-assault cases in eleven large counties in 2000) with id. at 49 tbl.6.11 (457 of those defendants ultimately reached adjudication).

${ }^{15}$ See $i d$. at $49 \&$ tbl.6.13 ("The probability of being convicted of a felony was about ... 48.1\% ....").

${ }^{16}$ See generally Reva B. Siegel, "The Rule of Love": Wife Beating as Prerogative and Privacy, 105 YALE L.J. 2117 (1996) (discussing how the history of chastisement in America has negatively affected the way the legal system deals with modern domestic violence).

${ }^{17}$ See id. at 2123-25 ("As master of his household, a husband could command his wife's obedience, and subject her to corporal punishment or 'chastisement' if she defied his authority.").

${ }^{18}$ See id. at 2165-71 (discussing cases that provided a marital-privacy rationale for failure to enforce wives' tort and contract claims against their husbands and for failure to resolve disputes through the criminal justice system); $c f$. Hynson v. City of Chester, Legal Dep't, 864 F.2d 1026, 1031 (3d Cir. 1988) (holding that differential police treatment of domestic and public violence does not constitute a violation of the Fourteenth Amendment Equal Protection Clause "absent a showing of an intent, purpose or effect of discriminating against women"). 
par with or even exceed criminal enforcement in cases of public violence. ${ }^{19}$ Yet, as episodes like that of Brett and Kim Myers demonstrate, echoes of that history can still be heard in today's legal system. Questions surrounding how domestic violence differs from public violence and why it might demand different legal treatment remain relevant.

René Girard, a French religious anthropologist, argues in his 1972 work, Violence and the Sacred, that violence is an inevitable element of society. ${ }^{20}$ Violence exists, and once aroused it threatens to snowball throughout society and cause chaos. ${ }^{21}$ In Girard's theory, society uses ritual to alleviate this violence on the theory that violence can be channeled into a sacrificial victim that, by being destroyed, can both provide an outlet for violence and restore social order. ${ }^{22}$ Some legal scholars have found Girard's framework helpful for understanding treatments of violence in the law, particularly with respect to capital punishment, ${ }^{23}$ but it seems no one has seriously considered its implications for the problem of domestic violence.

The American legal system has historically been unwilling to heavily penalize domestic violence-private violence - because, as I shall demonstrate, it has tacitly viewed victims of such violence as sacrifices providing an outlet against public violence. This article will explore the link between the Girardian model of sacrifice and the American legal system's historical treatment of domestic violence. In Part II, I will discuss the evolution of that treatment, looking at examples in the criminal justice system from police and courts. In Part III, I will turn to the Girardian sacrifice structure as a descriptive model of this domestic-violence tolerance, incorporating ideas from other ritual anthropologists. Finally, in

\footnotetext{
${ }^{19}$ See Bure $\Lambda$ U OF JUSTICE STATISTICS, supra note 11 , at 49 tbl.6.11.

${ }^{20}$ See René Girard, Violence And THE SaCred 2-4 (Patrick Gregory trans., Johns Hopkins Univ. Press 1977) (1972).

${ }^{21}$ See $i d$. at 14-15 ("Every time [violence] turns up in some part of the community, it threatens to involve the whole social body.").

${ }^{22}$ See id. at 8 .

${ }^{23}$ See, e.g., Donald L. Beschle, What's Guilt (or Deterrence) Got to Do With It? The Death Penalty, Ritual, and Mimetic Violence, 38 WM. \& MARY L. RLV. 487, 525-35 (1997); Donald L. Beschle, Why Do People Support Capital Pumishment? The Death Penalty as Community Ritual, 33 CoNN. L. REV. 765, 777-88 (2001); Roberta M. Harding, Capital Punishment as Human Sacrifice: A Societal Ritual as Depicted in George Eliot's Adam Bede, 48 BuFF. L. REV. 175, 190-208 (2000); see also James McBride, Revisiting a Seminal Text of the Law and Literature Movement: A Girardian Reading of Herman Melville's Billy Budd, Sailor, 3 MARGINS 285, 314-18 (2003) (reading Billy Budd as a Girardian condemnation of the law for the use of an innocent victim as a scapegoat).
} 
Part IV, I will explain how this new understanding can inform feminist theories of domestic violence and a practical understanding of the publicprivate relationship.

\section{TOLERATING DOMESTIC VIOLENCE}

Until the late nineteenth century, chastisement was the dominant common-law rule governing violence between a husband and wife. ${ }^{24}$ Generally, the law did not permit marital violence. But a husband was "master of the household" and his wife "obliged to obey." 25 The husband and wife constituted one legal unit; in civil and criminal courts they were answerable as the same person. ${ }^{26}$ Blackstone explains that, as a logical consequence of this legal structure, "[t]he husband ... might give his wife moderate correction. For, as he is to answer for her misbehaviour, the law thought it reasonable to intrust him with this power of restraining her, by domestic chastisement, in the same moderation that a man is allowed to correct his apprentices or children ...."27

American courts were willing to recognize chastisement as a defense for battery or as an upper limit on a husband beating his wife. In Bradley $v$. State, the Supreme Court of Mississippi reasoned that a judicial investigation of "[f]amily broils and dissentions ... [would] cast[] a shade over the character of those who are unfortunately engaged in the controversy. . . . [L]et the husband be permitted to exercise the right of moderate chastisement . . . ."28 In 1852, the Supreme Court of North Carolina ruled that a beaten wife who did not suffer "a lasting injury or great bodily harm" could not stand witness against her husband's assault. ${ }^{29}$ Chastisement was not limited to the South; in 1857, the Pennsylvania Supreme Court held that a husband's use of force did not necessarily entitle his wife to a divorce:

A man . . . has a right to a reasonable control of [his wife's] actions, as he is accountable, in many respects, for her

${ }^{24}$ See Siegal, supra note 16, at 2118 "The Anglo-American common law provided that a husband, as master of his household, could subject his wife to corporal punishment or 'chastisement' so long as he did not inflict permanent injury upon her.").

${ }^{25} \mathrm{Id}$. at $2122-23$.

26 See 1 William Blackstone, Commentaries *430 ("By marriage, the husband and wife are one person in law ....").

${ }^{27} I d$. at $* 432$.

${ }^{28} 1$ Miss. (1 Walker) 156, $158(1824)$.

${ }^{29}$ State v. Hussey, 44 N.C. (Busb.) 123, 127 (1852) (per curiam). 
conduct. It is a sickly sensibility which holds that a man may not lay hands on his wife, even rudely, if necessary, to prevent the commission of some unlawful or criminal purpose, or the use of a butchers-knife against a relative; some allowance should be made for the frailties of human nature; a man may sometimes, on sudden impulse, be betrayed into the commission of an act, or a harsh expression, for which, in a moment after, he might be repentant and sorrowful. $^{30}$

By the end of the nineteenth century, state courts had almost universally rejected the formal chastisement rule. ${ }^{31}$ In 1893, the Supreme Court of Mississippi announced that Bradley's "blind adherence . . . to revolting precedent has long been utterly repudiated in the administration of criminal law in our courts. $" 32$

The twentieth century did not destroy the assumptions underlying the chastisement doctrine; it merely transferred them to subtler practices. Cases such as the Third Circuit's Hynson v. City of Chester ${ }^{33}$ and Brown v. Grabowski $i^{34}$ made clear that the American justice system remained willing to treat domestic violence as a private matter, sufficiently different from public violence to justify special legal treatment. In Hynson, the mother and children of a woman killed by domestic violence filed a Section 1983 action claiming that police officers violated the decedent's equal-protection rights by ignoring her earlier complaints. ${ }^{35}$ The Third Circuit held that, even in light of evidence of a police policy of treating domestic violence cases differently from public violence, the plaintiffs could not prevail absent a showing that a motivating factor behind the policy was genderbased discrimination. ${ }^{36}$ Under similar facts in Brown, the court held that, despite the district court's finding of "a municipal plan or policy evincing deliberate indifference to the constitutional rights of domestic violence victims,, 37 domestic violence victims were not necessarily entitled to the

${ }^{30}$ Richards v. Richards, 1 Grant 389, 392-93 (Pa. 1857).

31 See Siegel, supra note 16, at 2129-30 ('[B]y the late 1870 's, there was no judge or treatise writer in the U.S. who recognized a husband's prerogative to chastise his wife.")

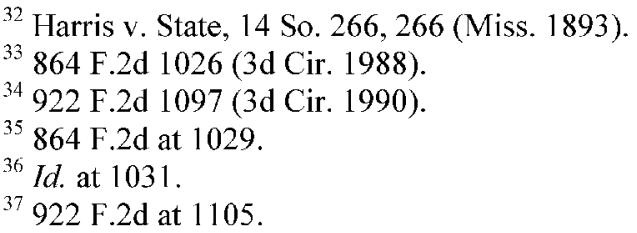


recovery of damages. Because of the dearth of scholarship or case law on the equal protection rights of domestic violence victims at the time of the events in Brown, the victim's right to equal protection had not been "clearly established and clear in its contours." 38

The policies at issue in Hynson and Brown, like the old chastisement rule, are the result of belief in what Katherine O'Donovan has called "a private domain of subjectivity, morality and the personal [that is] "not the law's business' [and leads] to non-intervention in domestic life." ${ }^{39}$ Donileen Loseke and Richard Gelles suggest that the result of such a view is "experiences with family violence [being] 'swept under the carpet" because they are "private family matters." model of political assumptions that was operative in Canada's past treatment of domestic violence and that could explain the bizarre outcomes of cases like Kim Myers's:

While it may have been possible to prove a charge of intimate assault other than through a wife's testimony, the enforcement of the law by the police, prosecution, and the courts was low level and erratic. When police did respond to "domestics," they often attempted to reconcile the parties, and they rarely laid charges .... . Such 'inaction' was justified ideologically by the state on the basis of preserving family unity and stability. Thus, the law has been implicated as

${ }^{38} \mathrm{Id}$. at $1118-19$.

${ }^{39}$ KATHERINE O'DONOVAN, SEXUAL DivisIONS IN THE LAW 11 (1985). Though this paper is confined to the United States, the problems that the legal concept of the private presents for female victims of domestic violence occur all over the world. See Hilary Charlesworth, Worlds Apart: Public/Private Distinctions in International Law, in PubliC AND PRIVATE: FEMINIST LEgAL DEBATES 243, 254-55 (Margaret Thornton ed., 1995) (arguing that international law, in dealing with public violence involving the state, has neglected the human-rights issue of private violence against women); see also CATHARINE MACKINNON, ARE WOMEN HUMAN? AND OTHER INTERNATIONAL DIALOGUES 276-77 (2006) (postulating that international human-rights law may have been wary of confronting domestic violence because of the complexities entailed in its private nature).

${ }^{40}$ Donileen R. Loseke \& Richard J. Gelles, Examining and Evaluating Controversies on Family Violence, Introduction to CURRENT CONTROVERSIES ON FAMII Y VIOLFNCF, at x (Richard J. Gelles \& Donileen R. Loseke eds., 1993); cf. Donileen R. Loseke et al., Understanding Controversies on Family Violence, Introduction to CURRENT CONTROVERSIES ON FAMILY VIOLENCE, at xi (Donileen R. Loseke et al. eds., 2d ed. 2005) ("Attempts to generate concern for the formerly defined 'private troubles' of family violence did not immediately galvanize an unaware public and apathetic public policy system."). 
playing a fundamental role in maintaining the boundary between public and private in the area of intimate violence against women. $^{41}$

\section{GIRARD AND VIOLENCE AS A CONTAINER}

The fundamental feminist critique of legal regime regarding the dichotomous nature of public and private violence is based in the discrepant outcomes it affords men and women. In Toward a Feminist Theory of the State, Catharine MacKinnon argues that "[t]he law of privacy treats the private sphere as a sphere of personal freedom. For men, it is. For women, the private is the distinctive sphere of intimate violation and abuse, neither free nor particularly personal." 42

Feminists have argued that men perpetuate this public-private divide because they are not the ones who suffer under it. MacKinnon, for instance, contends that " $[\mathrm{m}] \mathrm{en}$ 's realm of private freedom is women's realm of collective subordination." ${ }^{43}$ Robin West makes this discrepancy even clearer: "[p]rotecting the privacy and freedom of individuals to do and say as we wish in our private, intimate lives frees men to oppress, abuse, exploit or, in the extreme, to rape, and thereby further weaken women."44 MacKinnon and West are keen to discern why men might not care or notice how the barrier between a public sphere, where violence is banned, and a private sphere, where violence is to some extent permitted, disfavors women. Both critiques fall short, however, of explaining why men, and by extension male-run society, might erect and preserve this barrier between private and public spheres.

Here it is useful to examine conceptions of violence from outside the feminist-legal literature. French sociological thought provides a rich exploration of the meanings of violence in society. In particular, the work of René Girard constructs a model of ritualistic violence from a sociological-religious perspective that suggests reasons why male-run

\footnotetext{
${ }^{41}$ Jennifer Koshan, Sounds of Silence: The Public/Private Dichotomy, Violence, and Aboriginal Women, in Challenging THL Public/Privatl Divide: Fliminism, L $\Lambda$ W, $\Lambda$ ND PUBLIC PoliCy 87, 90 (Susan B. Boyd ed., 1997); see also Michele Madden Dempsey, What Counts as Domestic Violence? A Conceptual Analysis, 12 WM. \& MARY J. WOMEN \& L. 301, 312 (2006) (providing an overview of the implications of domestic violence's location in the "private" home).

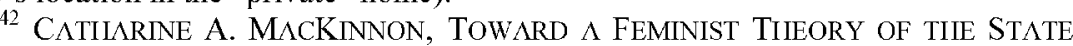
$168(1989)$.

${ }^{44}$ Robin West, Reconstructing Liberty, 59 TENN. L. REV. 44I, 462 (1992).
} 
society would permit and preserve a distinct private sphere wherein it tolerates violence.

\section{A. Girard's Theory of Violence}

Girard tackles the question of what role sacrifice plays in primitive societies. ${ }^{45}$ For Girard, the fundamental social interaction is rivalry or, as he deems it, "mimetic desire." causes of violence-scarce resources, for instance-are merely attractive nuisances distracting attention from the real source, our rivals: "[r]ivalry does not emerge because of the fortuitous convergence of two desires on a single object; rather, the subject desires the object because the rival desires it." 47 More and more individuals, exposed to this rivalrous dynamic, will be sucked into it through their own mimetic desire, hence the phenomenon will snowball. Rivalry is therefore both contagious and self-replicating. Thus, "[t]he slightest outbreak of violence can bring about a catastrophic escalation.,"

According to Girard, primitive societies lack a legal system, so they have few effective ways of dealing with the inevitable outbreak of chaotic violence. ${ }^{49}$ Rather than secular laws, these primitive societies turn to religion to provide a framework for dealing with violence:

In primitive societies the risk of unleashed violence is so great and the cure [ever-expanding vengeance] so problematic that the emphasis naturally falls on prevention. The preventative measures naturally fall within the domain of religion, where they can on occasion assume a violent character. Violence and the sacred are inseparable. ${ }^{50}$

For Girard, this religious framework means ritualistic violence, namely, sacrifice. ${ }^{51}$ Since "only violence can put an end to violence," chaotic violence, rather than being quelled, must be channeled into a

\footnotetext{
${ }^{45}$ See GIR $\wedge$ RD, supra note 20 , at 6-8, 21-22.

${ }^{46} I d$. at 146.

${ }^{47} \mathrm{Id}$. at 145 (emphasis in original).

${ }^{48} \mathrm{Id}$. at 30 .

${ }^{49} \mathrm{Id}$. at $18-19$.

${ }^{50} I d$. at 19.

${ }^{51} I d$. at 18 .

${ }^{52} I d$. at 26.
} 
sacrificial "surrogate victim." itself as destroying both the source of the disorder and its own salvation; hence, the scapegoat, or pharmakos, ${ }^{54}$ takes on a dual role:

On the one hand he is a woebegone figure, an object of scorn who is also weighed down with guilt; a butt for all sorts of gibes, insults, and of course, outbursts of violence. On the other hand, we find him surrounded by a quasi-religious aura of veneration; he has become a sort of cult object. This duality reflects the metamorphosis the ritual victim is designed to effect; the victim draws to itself all the violence infecting the original victim and through its own death transforms this baneful violence into beneficial violence, into harmony and abundance. ${ }^{55}$

The perfect victim is both an insider and an outsider, or liminally transformed from one into the other. ${ }^{56}$ In this transitional state, the scapegoat is sacred. ${ }^{57}$ In a classic account of ritual symbolism that aligns with Girard's theory, Victor Turner maintains that ritual honors the social order by inverting it:

What is interesting about liminal phenomena ... is the blend they offer of lowliness and sacredness, of homogeneity and comradeship. We are presented, in such rites, with a "moment in and out of time," and in and out of secular social structure, which reveals, however fleetingly, some recognition (in symbol if not always in language) of a generalized social bond that has ceased to be and has

${ }^{53}$ Id. at 79.

${ }^{54} \mathrm{Id}$. at 95 . Girard uses a variation on the classical Greek word pharmakon, which "means both poison and the antidote for poison, both sickness and cure-in short, any substance capable of perpetrating a very good or very bad action . . .."Id. The scapegoat, like Homer Simpson's alcohol, is "the cause of, and solution to, all of life's problems." The Simpsons: Homer vs. the Eighteenth Amendment (Fox television broadcast Mar. 16, 1997).

${ }_{55}$ GIRARD, supra note 20 , at 95.

${ }^{56} \mathrm{Id}$. at $270-72$.

${ }^{57}$ See id. at 270-71 (comparing victims of violence to ritual sacrifice victims such as animal and outsiders). 
simultaneously yet to be fragmented into a multiplicity of structural ties. 58

Girard's vision is the same as Turner's: through one final act of ordered violence, the disordered violence ceases.

The essential move here is channeling violence into what society deems a more palatable direction. The scapegoat serves as a container for wider social violence. Jean-Pierre Dupuy, in interpreting Girard's theory, revealed that contain here represents both its ordinary definitions. ${ }^{59}$ Webster's Dictionary notes that contain means both "to keep within limits, as restrain, control, check, [or] halt," and "to have within, hold, comprise, [or] include." 60 According to Dupuy, the act of sacrifice "contains disorder, in both senses of the word 'contain': it has within itself, and it holds it back." $" 61$

\section{B. Applying the Model to Domestic Violence}

Society, dominated by men, has erected a wall between the public and the private, and it considers violence in the former significantly more dangerous, blameworthy, and unbearable than violence in the latter. ${ }^{62}$ It is easy for men to take this view, as feminists like West and MacKinnon have noted, because they tend not to be the victims of violence in the private sphere. $^{63}$

But the Girardian model goes further. To Girard, society opts to tolerate ordered violence because of the belief that it might mitigate disordered violence. In this model, the private sphere provides the needed order: private violence is ideally limited geographically (to within or around the home) ${ }^{64}$ and temporally (to those times at which the abuser and

\footnotetext{
${ }^{58}$ Victor Turner, The Ritual Process: Structure ANd ANTI-STRUCTURE 96 (Aldine 1995) (1966).

59 See Jean-Pierre Dupuy, The Self-deconstruction of the Liberal Order, 2 CONTAGION 1, 13-14 (1995) (discussing the liberal order's containment of disorder).

${ }^{60}$ MERRIAM-WEBSTER's COLLEGIATE DICTIONARY 269 (11 th ed. 2004) (internal examples and punctuation omitted).

${ }_{62}^{6}$ Dupuy, supra note 59, at 14.

${ }^{62}$ See supra Part II.

63 See Bureau of Justice, Statistics, Family Violence Statistics InCLUding STATISTICS ON STRANGERS AND ACQUAINTANCES 22 tbl.4.1 1 (2005) ("Females were $84 \%$ of spouse abuse victims and $86 \%$ of victims of abuse at the hands of a boyfriend or girlfriend.").

64 The Myers case is unusual among domestic-violence incidents because it occurred in the street; theorists could quibble over whether it remains a true private
} 
victim are together), and it selects its victims from a limited pool (sometimes children, usually wives or partners, and almost always women). Hence, society tolerates private violence because it views the private sphere as an outlet, a container for violence. Male dominance and violence in the home will stave off violent disorder in the streets.

Some empirical evidence supports this intuition. Neil Jacobson and John Gottman's study of the different types of batterers suggests that at least one group, which they dub "Cobras," is comprised of antisocial and potentially psychopathic men who tend to have criminal records and view violence in the home as a means to gratification in life. ${ }^{65}$ Viewing this group of men through a Girardian framework, one could infer that these men might, but for the fortuitous circumstance of having an intimate victim to manipulate within the private, commit greater violence in the public sphere. The findings of other psychologists suggest that frustrated weaker men, dominated by stronger men in the public sphere, might turn to the private sphere to let out their aggression. ${ }^{66}$

Also implicit in this model is the concept of home as sacred ground, a strange location that is both a place of tension and a haven from the outside world. Like Girard's sacrificial act, the violent marital home encompasses both transgression and a curb on wider disorder. Its inhabitant, the wife or female intimate partner, is the scapegoat. On the one hand, her batterer views her as the vile source of frustration, tension, and violence. As Barbara Ehrenreich noted of the Playboy revolution of the $1950 \mathrm{~s}$, men may perceive wives as carping crushers of spirit, domineering deprivers of freedom, and money-grubbing demanders of their share of men's own good life. ${ }^{67}$ On the other hand, the wife is simultaneously sacred in the transition she provides from disorder to order, from chaos to haven, even if her role is that of victim. ${ }^{68}$ Jacobson and Gottman noted that

violence case at all.

${ }^{65}$ NeIL S. JACOBSON \& JOHN M. GOTTMAN, When MEN BAT'TER WOMEN: NEW INSIGHTS INTO ENDING ABUSIVE RELATIONSHIPS 36-39 (1998).

${ }^{66}$ See generally Kristin L. Anderson \& Debra Umberson, Gendering Violence: Masculinity and Power in Men's Accounts of Domestic Violence, 15 GENDER \& SOC'Y $358,359,372$ (2001) (demonstrating that male abusers often use domestic violence as a way of establishing the masculine dominance they otherwise feel is threatened in society).

${ }^{67}$ Barbara Ehrfnreich, The Hearts of Men: AmErican Dreams and the FLIGHT FROM COMMITMENT 42-47 (1983); see also Anderson \& Umberson, supra note 66, at 367-68 (discussing batterers' accounts of their female partners as controlling); id. at 371 (recounting some batterers' resentment toward a perceived cultural bias against men).

${ }^{68}$ Wrapped up in this dichotomy of views of marriage and womanhood is, 
the more numerous type of batterers, "Pit Bulls," are "motivated by a fear of being left" and thus desperately cling to their wives; ${ }^{69}$ their jealous rage is almost a form of worship. ${ }^{70}$

The fact that modern society has developed a complex, legalized social structure does not necessarily mean it has escaped the Girardian model for ritualistic violence. Girard stresses that even advanced and secular societies are rooted in primitive ones, and that law is the continuation of ritual by other means: "Even when this theology disappears, as has happened in our culture, the transcendental quality of the system remains intact. Centuries can pass before men realize that there is no real difference between their principle of justice and the concept of revenge." ${ }^{, 71}$

\section{PRiVATE Violence And FEMINISM}

The Girardian model of ritual violence, translated into the modern concept of private violence, has important implications for the work of feminist legal theorists. There are three basic areas in which this newly applied concept can have an impact: in transforming women from scapegoats into regular members of society, in transforming gendered dominance of the private sphere to protect against reciprocal violence, and in transforming the law governing domestic violence to address the public-

undoubtedly, a dual view of sexuality and procreation as both sinful and sacred. See, e.g., Elaine PAGELs, ADAM, EVE, AND THE SERPENT 26-27 (Vintage Books 1989) (1988) (discussing Christian conceptions of marriage, celibacy, and sexual intercourse). American society, though efficient at translating religious values into secular morality, has nevertheless been shaped by monotheistic, particularly Protestant Christian, ideas of the proper relationship between men and women. See, e.g., NATHANIEL HAWTHORNE, THE SCARLET LETTER (4th rev. ed., Norton 2004) (1850) (exploring themes of Puritanism and sexuality in early America); Gail Bederman, "The Women Have Had Charge of the Church Work Long Enough": The Men and Religion Forward Movement of 1911-1912 and the Masculinization of Middle-Class Protestanism, in A MIGIITY BAPTISM: RACE, GENDER, AND THE CREATION OF AMERICAN PROTESTANTISM 107 (Susan Juster \& Lisa MacFarlane eds., 1996) (discussing the influence of religion on American gender roles through the lens of an early-twentieth-century movement). Though these ideas may be inexorably intertwined with men's double perspective on their wives, I leave discussion of their implications to another time.

${ }^{69}$ JACOBSON \& GOTTMAN, supra note 65, at 36-39.

${ }^{70}$ Think here of Marlon Brando as Stanley Kowalski in a stained undershirt crying "STELLAHHH!!!" outside his New Orleans apartment to the wife he just struck in A Streetcar Named Desire (Warner Bros. 1951).

${ }^{71}$ Girard, supra note 20, at 23-24. 
private divide. Ultimately, the Girardian framework provides a built-in solution to the violence which it defines as a central societal problem. ${ }^{72}$

\section{A. Transforming Scapegoats}

I have argued in the preceding pages that part of the problem with society's treatment of domestic violence is that it views the victimsoverwhelmingly women - as Girardian scapegoats. Here, I maintain that this treatment is rooted in a view of women as fundamentally different from men, an out-group living amongst (or within) the in-group. This state of affairs may be all the more true, as critical race feminists point out, for women of color. The problem of the woman as scapegoat calls for a wholly revolutionary solution: society must reconceptualize the differences it now views as gendered into variations among men and women rather than between them.

One strand of feminist legal theorists posits that women are different, perhaps essentially so, from men. Scholars like Carol Gilligan ${ }^{73}$ and Robin West $^{74}$ have argued that differences in psychology and experiences give women a distinct outlook on human interactions. Critical race feminists like Angela Harris go even further, arguing that other distinctions, particularly race and class, impact women's experiences and worldviews. ${ }^{75}$ The hypothesis derived from the theories of Girard and, to a lesser extent, Turner, which postulates that differences permit scapegoating, can provide a causal explanation for violence against women consistent with these difference-focused feminists' views.

Carol Gilligan focuses on males' and females' different strategies for evaluating moral quandaries. ${ }^{76}$ In one passage of her 1982 psychological critique, In a Different Voice, Gilligan examines the responses of two young people, a boy and a girl, to a hypothetical moral dilemma. ${ }^{77}$ The boy evaluates the problem through logical rules, while the girl approaches it through a framework of relationships and caring, a distinction that leads the

\footnotetext{
${ }^{72}$ See infra Section IV.B.

73 See generally Carol GILligan, In A Dililirlent VOICl: PSYChological TIIEORY AND WOMEN'S DEVELOPMENT 25-29 (Harvard Univ. Press 1982).

${ }^{74}$ See generally Robin L. West, The Difference in Women's Hedonic Lives: A Phenomenological Critique of Feminist Legal Theory, 3 WIS. WOMFN'S L.J. 81, 140 (1987).

75 See generally Angela P. Harris, Race and Essentialism in Feminist Legal Theory, 42 STAN. L. REV. 581, 585 (1990).

${ }^{76}$ CAROL GIIIIGAN, supra note 73 , at 25 .

${ }^{77} \mathrm{Id}$. at $25-29$.
} 
original psychological appraiser to score the boy more highly. ${ }^{78}$ The problem, Gilligan suggests, isn't that the girl's answers are normatively worse, but that the entire psychological process, from interview to evaluation, fails to appreciate their validity: "while [the boy's] assumptions about agreement are confirmed by the convergence in logic between his answers and the questions posed, her assumptions are belied by the failure of communication, the interviewer's inability to understand her response.,"79

Unlike Gilligan, West directly confronts feminist legal theory, in particular liberal and radical conceptions of its goal. West argues that, while both male and female social conceptions value autonomy, the collective subjective experience of women effectively lacks autonomy as biology forces, and society conditions, women to be giving. ${ }^{80}$ Women, West argues, are fundamentally different from men because their experience is fundamentally different. ${ }^{81}$ This difference, which West, with shades of Gilligan, considers a "relational" rather than "autonomous" sense of being, ${ }^{82}$ essentially dictates that women cannot truly consent within relationships, at least in any liberal sense of the word. ${ }^{83}$ In the specific context of domestic violence, persistent fear of the batterer forces women to abandon autonomy in favor of emphasis on and concern for the batterer: "the near universal response to the pervasive fear with which a battered woman lives is to redefine herself as a giving rather than a liberal self." This lack of autonomy may even result in women no longer fitting within society's problematic definition of human being. ${ }^{85}$

These types of differences make women perfect victims for Girardian sacrifice. Women are an out-group amongst the in-group, perhaps discrete but not insular. Their different worldviews and experiences allow them to easily be branded outsiders while simultaneously remaining ostensibly members of society. This dangerous contradiction is what makes women fit the scapegoat archetype. For Girard, the scapegoat,

\footnotetext{
${ }^{78} \mathrm{Id}$.

${ }^{79} \mathrm{Id}$. at 29. For a discussion of various scholars' critiques of Gilligan and alternate explanations for the seemingly gendered outcomes, see Bridget J. Crawford, The Profits and Penalties of Kinship: Conflicting Meanings of Family in Estate Tax Law, 3 PIITI. TAX RLV. 1, 41 n.202 (2005), and sources cited therein.

${ }^{80}$ West, supra note 74 , at 140 .

${ }^{81} \mathrm{Id}$. at 142 .

${ }^{2}$ Id.; cf. GILLIGAN, supra note 73, at 25-29 (contrasting a masculine, rigid, "rational" set of ethics with a relational, feminine "ethic of care").

${ }^{83}$ West, supra note 74, at 93-94.

${ }^{84} \mathrm{Id}$. at 99 (emphasis omitted).

${ }^{85}$ See id. at 142 ("[F]eminists should insist on women's humanity ... and on the wrongness of the dominant conception of what it means to be a 'human being."').
} 
or "surrogate victim," is not "simply foreign to the community. Rather, he is seen as a 'monstrous double.' He partakes of all possible differences within the community, particularly the differences between within and without .... Thus, the surrogate victim constitutes both a link and a barrier between the community and the sacred." 86 Because of women's simultaneous sameness and difference, they are marginalized, liminal in the Girard-Turner sense, and hence prime candidates for sacrificial victims. ${ }^{87}$

Angela Harris's critique of gender essentialism adds a layer of complexity to the Gilligan and West difference theories, as Harris combines her feminist examination with one incorporating issues of race. To Harris, "the experience of black women is too often ignored in both feminist theory and in legal theory, and gender essentialism in feminist legal theory does nothing to address this problem." $" 88$ Indeed, situating gender as a fundamental category of different experience, as West does, "reduce[s] the lives of people who experience multiple forms of oppression [such as sexism and racism] to addition problems," woman of color is not primarily a female self or a colored self, but a bothand self., 90 Gender essentialism further allows latent racism to creep into the feminist legal discourse. ${ }^{91}$ But Harris's theory inevitably leads to the same problems for sacrificial violence as the premise it disavows.

Harris's solution isn't the obliteration of categories of oppression, but "mak[ing] our categories explicitly tentative, relational, and unstable." Yet in the Girardian view, unstable and tentative differences are at the very core of the liminality that allows society to identify scapegoats. ${ }^{93}$ For Girard and Turner, Harris's form of difference would emphasize the liminal, and therefore dangerous, status of women, women of color, and other groups oppressed by private violence. The increased liminality of these categories would only enhance women's susceptibility to violence as a sacrificial entity. While Harris's diagnosis may be more complex than

${ }^{86}$ GIRARD, supra note 20 , at 271 .

${ }^{87}$ Compare id. ("[R]itual victims tend to be drawn from categories that are neither outside nor inside the community, but marginal to it: slaves, children, livestock.") with TURNER, supra note 58, at 125 ("[Liminal sacrificial victims] all have this common characteristic: they are persons or principles that (1) fall in the interstices of social structure, (2) are on its margins, or (3) occupy its lowest rungs.").

${ }^{88}$ Angela P. Harris, Race and Essentialism in Feminist Legal Theory, 42 STAN. L. RFV. 581, 585 (1990).

${ }^{89} \mathrm{Id}$. at 588 .

${ }^{90} \mathrm{Id}$. at 604 .

${ }^{91}$ See Id. at 589 (discussing the practical advantages of feminist essentialism).

${ }^{92} I d$. at 586.

${ }^{93}$ GIRARD, supra note 20, at 271 . 
essentialist difference feminists like Gilligan and West, the Girardian perspective suggests the cure is worse than the disease.

Linda Ammons has a different notion of the oppressive experience of women of color from that of Harris-one that effectively anticipates, at least for African American women, the problem that social scapegoating poses for combating domestic violence. ${ }^{94}$ Ammons believes that African American women are disadvantaged as battered-woman defendants in spouse murder trials. ${ }^{95}$ Her theory is based on the premise that many of society's stereotypes of black women run counter to stereotypes of women in general. ${ }^{96}$ Stereotypes of black women include "Mammy, Aunt Jemima, and Jezebel," and more recently "Sapphire, the matriarch, and the welfare queen." 97 Though these are in many respects negative depictions of African American women, vulnerable they are not. ${ }^{98}$ The conception that these black female stereotypes are not vulnerable - like women in general, with the white woman as the archetype - works against social acceptance of a claim that they can be victims of domestic violence. ${ }^{99}$

Society's view of black women as nonvictims does not result in them being any less victimized; like all women, they remain actually vulnerable to violence in the private sphere. ${ }^{100}$ Stereotypes of black women as nonvulnerable cannot eliminate them as scapegoat candidates. To be scapegoats, according to the Girardian scheme, they need only be different; vulnerability is just another dimension of difference, not a special protection against scapegoating. Indeed, if society views black women as different from men because they are, first, women and, second, different from other women because they are not vulnerable, these compound

${ }^{94}$ See Linda L. Ammons, Mules, Madonnas, Babies, Bathwater, Racial Imagery, and Stereotypes: The African American Woman and the Battered Woman Syndrome, in CRITICAL RACE FEMINISM: A READER 261 (Adrien Katherine Wing ed., 2d ed. 2003) (analyzing the use of battered woman syndrome in criminal law and its effect on black women).

95 Id. at 261.

${ }^{96} \mathrm{Id}$.

${ }^{97} \mathrm{Id}$. at 264 (internal references omitted).

${ }^{98}$ See id. (discussing how negative stereotypes of black women can also convey their strength and independence).

99 Id. at 26465.

100 African Americans account for about a quarter of U.S. domestic-violence victims, BUREAU OF JUSTICE STATISTICS, supra note 11 , at 32 , though they comprise only about 12 percent of the population, U.S. CENSUS BURE $\Lambda U, 2005$ AMERIC $\Lambda N$ COMMUNITY SURVEY tbl.B02001, http://factfinder.census.gov/servlet/DTTable? bm $=y \&-g e o \_i d=01000 U S \&-d s \_n a m e=A C S \_2005$ EST_G00_\&-mt_name $=A C S \_2005$ _ EST_G2000_B02001 (last visited Nov. 22, 2007). 
differences may create a state of flux-mirroring Harris' unstable categories - that fits the liminal-difference model perfectly.

The only way to avoid this result - to prevent women from becoming scapegoats in private violence because of their differences from what society views as its own normal members, namely, men is to reconceptualize such differences as nongendered variations in a universal, inclusive humanity. This is, of course, easier said than done. To advance this goal, the law must begin to treat problems traditionally conceptualized as belonging only to women as instead affecting all society, not exclusively women. ${ }^{101}$

The shift will largely have to come through identifying and adopting differences, previously perceived as gender-based, as instead non-genderspecific variations in the human experience. Any real impact would stem from a radical change in the norms expressed in those institutions that have a direct impact on culture, such as education and the media. Social education, for instance, might permit society to acknowledge the differences noted by Gilligan, between the logical-rules and relationalcaring approaches to moral dilemmas, without attributing these differences to gender. Dislodging these distinctions from a conceptual gender divide would permit social evaluation on a normative basis without loading them with gender-based judgments - and would permit recognition of those situations in which a man takes the relational approach or a woman the logical approach without viewing them as deviant. Likewise, representations in the media that emphasize the concept of gender as a spectrum, rather than a set of discrete categories that are either stable, as in West's conception, or unstable, as in Harris's, could, to the extent the audience accepts them, go a long way toward unraveling the concept of woman as an inherently different other. ${ }^{102}$

Because it is conceptual rather than practical, this social shift presents challenges more difficult that other prescriptions derived from the Giradian model of domestic violence. A full understanding of what courses of action would lead to the necessary redefinition of woman requires a more thorough exploration than the structure of this article allows. Suffice it to say, the Girardian model's message for feminist legal theory is that society

${ }^{101}$ For a further discussion of feminist legal changes as a result of the Girardian concept of ritual violence, see infra Part IV.C.

${ }^{102}$ See, e.g., Surya Monro, Beyond Male and Female: Poststructuralism and the Spectrum of Gender, 8 INT'I. J. OF TRANSGENDERISM 3 (2005) (conceptualizing gender as a spectrum based on research with transgender identities). 
must deemphasize the perceived gender differences that have thus far left women open to being viewed as scapegoats.

Many feminists - West in particular, but likely Harris as wellwould question whether the category woman, freed of the differences derived from gender-specific examination, would retain any meaning whatsoever. But if accepting women alongside of men under the conceptual definition of person, with differences at the individual rather than categorical level, is necessary to eliminate the liminality that permits society to treat women as scapegoats, perhaps the aggregate benefits are worth the cost.

\section{B. Transforming Domination}

In addition to a redefinition of woman, the Girardian understanding of domestic violence challenges society to undertake a redefinition of private - or at least abandon the distinction between private and public violence. In light of this model, society uses the concept of domination to provide structure to the distinction between the private and public, attempting to create a closed private space where hierarchical or dominating violence may stave off chaotic violence in the public. Yet domination is ineffective at this task: violence, no matter the channel through which it is directed, begets more violence. Domination is less about the relationship between men and women-merely a mechanism by which societal violence is funneled - and more about the relationship between violence and mankind, a relationship society must transform to forestall all forms of violence.

Catharine MacKinnon's contribution to the feminist legal discourse is focusing the legal issue on a narrative of dominance. MacKinnon argues that the fundamental dynamic between men and women is the former dominating the latter, and that society has structurally accepted this through legal fictions that ignore the plight of women. ${ }^{103}$ For instance, if the legal regime "defines rape as intercourse with force or coercion and without consent," its premise is that intercourse with force or coercion but not without consent is permissible sex. ${ }^{104}$ This presents an odd set of equivalencies: "dominance plus submission [equals] force plus consent," which "equals sex, not rape." 105 If a man dominates, as men are wont to do, and a woman accepts that domination, according to a male standard of what

${ }^{103}$ See MACKINNON, supra note 42 , at 172.

${ }^{104} \mathrm{Id}$. at 172.

${ }^{105} \mathrm{Id}$. 
acceptance looks like, the act is protected. The structure thus preserves domination itself as a legitimate dynamic.

In MacKinnon's view, this perverse outcome of legitimized domination is no less likely in the domestic-violence arena than in that of rape. $^{106}$ In domestic violence, the legal mechanism that preserves such domination is not the fictive consent of the rape scheme but the proliferation of the private sphere. ${ }^{107}$ The private sphere is "man's sovereign castle, where most women remain for a lifetime, where women are mostly to be battered and sexually assaulted, and where they have no recourse because the private, by definition, is inviolable and recourse means intervention."108 MacKinnon's solution is to get women out of the home - and thus out of the private sphere - and into the public sphere, where women have "freedom of action, resources, and access to a larger world," and are "most equal" with men. ${ }^{109}$ For MacKinnon, freedom and equality keep score in a zero-sum game between men and women, and since "men have the most freedom at home, . . . women gain correspondingly greater equality, hence freedom, the farther away from home they go." 110 In her argument in favor of the Violence Against Women Act, MacKinnon envisions women seeking legal redress from the federal government as opposed to the state because the federal government is conceptually (and likely geographically) further from the maledominated home. ${ }^{111}$

MacKinnon and others have identified how the private sphere disadvantages women, and the Girardian model explains why society has nevertheless preserved and defended it as a site for sacrificial violence alienated from the public. ${ }^{112}$ The intuition is clear: dominance of one clear category of people over another means hierarchy and order, and ordered violence within such a hierarchy is necessary to stave off disordered violence. But even as it establishes the model for private violence as a container for chaotic violence, Girard's theory provides the solution to unraveling the premise that dominance is necessary.

\footnotetext{
${ }^{106}$ See CATHARINE A. MACKINNON, WOMEN's LIVES, MEN's LAWs 237 (2005) [hereinafter MACKINNON, WOMLN'S LIVLS].

${ }^{107} \mathrm{Id}$. at $236-37$.

${ }^{108} \mathrm{Id}$. at 237 .

${ }^{109} \mathrm{Id}$.

${ }^{110}$ Id.; see also Anderson \& Umberson, supra note 66, at 369-71 (discussing abusers' accounts of what they perceived as systemic bias in the legal system in favor of women).

111 MACKINNON, WOMEN'S LIVES, supra note 106, at 238.

${ }^{112}$ See supra Part III.B.
} 
One of Girard's central arguments is that controlled sacrificial violence may keep chaotic violence at bay. ${ }^{113}$ This establishes the basis for the concept of the private sphere in modern society as a place for ritual, tolerable, and "good" violence that can prevent "bad" violence. But another of Girard's essential arguments may undermine that justification: violence is reciprocal, contagious, and self-replicating-in short, unavoidable. ${ }^{114}$

Girard claims that "[v]iolence is like a raging fire that feeds on the very objects intended to smother its flames" because, "[t]he more men strive to curb their violent impulses, the more these impulses seem to prosper." 115 Though sacrifice serves as an attempt to contain violence through order, it remains merely an attempt: "Inevitably the moment comes when violence can only be countered by more violence. Whether we fail or succeed in our effort to subdue it, the real victor is always violence itself."116 Throughout his account, Girard refrains from normatively judging the structure of sacrifice as pertains to its goal of alleviating violence, instead methodically placing scare quotes around the "good" in " "good' violence." accomplishing when they undertake sacrificial rites in the midst of chaotic violence; he never claims they actually achieve anything.

Much scientific knowledge of the nature of domestic violence suggests that the proposition that violence begets violence carries the day. Though, as noted in Part III.B, one might expect that the opportunity for private violence would assuage the tendency of Jacobson and Gottman's "Cobras" to commit violence outside the home, in fact 44 percent of them have histories of violence outside the home. ${ }^{118}$ Both Cobras and Pit Bulls were much more likely to come from violent childhood households than the general population ${ }^{119}$ - further suggesting that earlier violence made them the violent people they would later become. Additional research has shown that those who follow the conventional self-help book wisdom and "blow off steam" when they are angry by hitting a punching bag subsequently act and feel more, not less, aggressive. ${ }^{120}$

113 See supra Part II.

${ }^{114}$ GIR $\Lambda$ RD, supra note 20, at 30 .

${ }^{115}$ Id. at 31

${ }^{116} \mathrm{Id}$.

${ }^{117}$ See id. passim.

${ }^{118} \mathrm{~J} \Lambda$ COBSON \& GOTTM $\Lambda \mathrm{N}$, supra note 65 , at 93-97.

${ }^{119}$ Id. at 94.

120 Brad J. Bushman, Does Venting Anger Feed or Extinguish the Flame? Catharsis, Rumination, Distraction, Anger, and Aggressive Responding, 28 
This evidence, understood through the Girardian framework of reciprocal violence, indicates that society's attempts to stave off public violence through tolerance of private violence are at best futile and at worst completely counterproductive. Violence in any form, however ordered, however private, will lead to more aggression and more violence throughout all domains. The outlook that violence is inevitable may be bleak, but the practical course of action is clear: rather than, as MacKinnon suggests, distinguishing the private as a province of male domination and the public as a haven of legal redress for women, ${ }^{121}$ society must focus on stamping out violence wherever it occurs. Orderly male dominance in the private sphere may increase disorderly violence in public, and it certainly does nothing to alleviate it. Since Girard's account of the nature of violence lends credence to MacKinnon's call for addressing the male dominance hierarchy through legal changes, this theoretical underpinning is further emphasized when Girard addresses the MacKinnon argument in its own terms: "[v]iolence is the heart and secret soul of the sacred," which "consists of all those forces whose dominance over man increases or seems to increase in proportion to man's effort to master them."122 The Girardian model includes a call to arms, a challenge to recognize that domination is not a solution to chaotic violence but a manifestation of it. In other words, as men attempt to dominate women through violence, violence dominates men.

\section{Transforming Law}

The Girardian model of private violence finally counsels in favor of a legal pragmatist approach to the problem of private violence. Pragmatic feminists believe in the ability to work for change within the existing legal framework, challenging laws piece by piece. Girard developed a concept of law as a replacement for sacrifice, a higher social order to do the work that channeled violence had previously been aimed at doing. The law has thus far been problematic, preserving domestic violence first through chastisement and ultimately through the public-private dichotomy. But law, as pragmatic feminists may recognize, is the ultimate tool for

PERSONAlity \& SOC. PSyCHOL. BULl. 724, 724 (2002); see also JACOBSON \& GOTTMAN, supra note 65 , at 725 ("[T] he activation of aggressive thoughts can engender a complex of associations consisting of aggressive ideas, emotions related to violence, and the impetus for aggressive actions.").

${ }^{121}$ MACKInNON, WOMEN's Lives, supra note 106, at 237-38; see supra text accompanying notes $109-10$.

${ }^{122}$ GIRARD, supra note 20, at 31. 
exploding that dichotomy, bringing private tragedies into the public light and leveling the field for victims of all violence.

Over the past few decades, those feminist legal theorists who have adopted a pragmatic, realistic approach to transforming law have effectuated the most concrete results. While philosophically abstract theorists have influenced legal discourse, erasure of Ruth Bader Ginsburg from legal history would impact the outcomes of landmark cases and law school classes significantly more than a similar removal of Mackinnon or Harris. ${ }^{123}$

Ginsburg defends the legal goal of formal equality from those theorists, particularly Gilligan or MacKinnon, who might attack it as essentially a capitulation, an agreement to fight men on men's own terms and resulting in, at best, a victory for women willing to act like men. ${ }^{124}$ In the 1970s, Supreme Court sex-discrimination cases, many of which Ginsburg played a role in, strove "to obtain thoughtful consideration of the assumptions underlying, and the purposes served by, sex-based classifications." "25 For Ginsburg, making the law gender-neutraleliminating those instances where the law, on its face, treats men and women differently, especially and most frequently subordinating women was both an important step toward true legal equality and, practically speaking, all that could have been done in the 1970s. ${ }^{126}$

The academic counterpart of Ginsburg on the bench and at the bar is Margaret Jane Radin. To Radin, feminism should be, and largely is, a pragmatist's endeavor. ${ }^{127}$ Radin argues that feminist legal theorists, caught in a "double bind," must make choices in the context of "nonideal justice: given where we now find ourselves, what is the better decision?" "28 This means "confront[ing] each dilemma separately and choos[ing] the alternative that will hinder empowerment the least and further it the

${ }^{123}$ As an advocate for the ACLU Women's Rights Project, Ginsburg argued several cases before the Supreme Court, including Frontiero v. Richardson, 411 U.S. 677 (1973), and Craig v. Boren, 429 U.S. 190 (1976), establishing the level of scrutiny for gender-based equal-protection claims. As a Supreme Court Justice, she wrote for the majority in United States v. Virginia, 518 U.S. 515 (1996), holding the Virginia Military Institute's policy of admitting only men unconstitutional.

${ }^{124}$ See Ruth Bader Ginsburg \& Barbara Flagg, Some Reflections on the Feminist Legal Thought of the 1970s, 1989 U. CHI. LEGAL F. 9, 17 (discussing successes achieved in utilizing the court structure to further goals of equality as answer to critics).

${ }^{125} \mathrm{Id}$. at 16

${ }^{126} \mathrm{Id}$. at $17-18$.

${ }^{127}$ Margaret Jane Radin, The Pragmatist and the Feminist, 63 S. CAL. L. REV. 1699,1707 (1990).

${ }^{128} \mathrm{Id}$. at 1700 . 
most." life and ... situatedness" is to dissolve "traditional dichotomies" such as that between "public (man) and private (woman)," a specific rejection that Radin suggests pragmatists have not yet adopted, but should. ${ }^{130}$

To pragmatic legal feminists the Girardian model offers a vision of the functions for which society depends on law. Girard argues that law is rooted in ritual; the development of the modern legal system is an efficient, secular version of the ritual system of order containing violence. ${ }^{131}$ Law is more effective than sacrifice because, whereas sacrifice must designate a surrogate victim in order to quell a widening cycle of vengeance, law makes sure "violence does indeed fall on the 'right' victim . . . with such force, such resounding authority, that no retort is possible." 132 This is clearly more just than the sacrificial system, but then justice is not a value by which ritual sacrifice measures its success. ${ }^{133}$

Girard's concept of law focuses on criminal law, but its implications spill over into legal theory as well. All law, according to the model, springs from ritualized violence as an extended attempt to systematize rules and procedures for ordering society. ${ }^{134}$ This requires instilling a judicial system with overwhelming authority, a "monopoly on the means of revenge" so authoritative "no group, not even the collectivity as a body, can challenge" it. ${ }^{135}$ This makes the modern legal system potentially dangerous: "like all modern technological advances, it is a two-edged sword, which can be used to oppress as well as to liberate." 136

Each of those two edges comes into play in the creation and preservation of the divide between the public and private spheres. In theory, the division is a means of liberating the community from chaotic violence by channeling violence into a realm of order; in practice, this dichotomy oppresses the community's sacrificial scapegoats, victims of domestic violence, through a system of domination and tolerance thereof.

Like Radin, Girard believes that a fundamental problem for society's victims is that they are caught in a double bind: they are expected to simultaneously follow the lead of their model "others" and refrain from

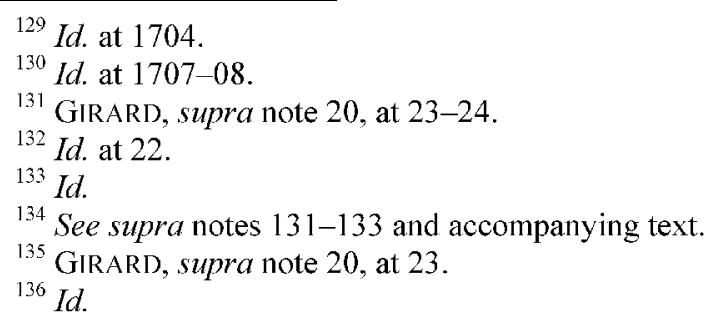


following because they are different. ${ }^{137}$ Girard argues that the only escape is "channeling ... energies into ritual forms." I3̂ If the modern, more effective corollary to ritual is the law, it follows that the law itself is where victims of the double bind must turn. The paradox this presents in the domestic-violence context is that law is both the source of the problem the private-public divide - and its solution.

The guidance that this theory provides for pragmatic feminists demands using the law's universal liberating aspects to overcome and demolish its more oppressive structures. Law may have served to preserve the public-private divide, but it has also provided justice for victims of violent criminals. The Girardian model thus supports using Radin's piecemeal system of relative outcomes to chisel away at the dominant dichotomy through utilization of the criminal justice system. For instance, laws that make prosecution of domestic-violence offenders mandatory even in the face of objections from the battered victim ${ }^{139}$ are preferable to those policies advocating nonprosecutorial resolutions to domestic disputes, as revealed in Hynson v. City of Chester, Legal Department, ${ }^{140}$ and Brown v. Grabowski. ${ }^{14 i}$ These latter policies preserve the private sphere of violence by treating it as a separate and less criminal problem than public violence.

The Girardian model also suggests that Ginsburg is right in advocating that feminists go further and effect reform of the legal system from within through both litigation and legislation. If making the law

${ }^{137} \mathrm{Id}$. at $147-49$. For Girard, this specifically refers to the mimetic problem that rivals command one another to both imitate them and avoid imitating them. See id. at 147 ("Man cannot respond to that universal human injunction, 'Imitate me!' without almost immediately encountering an inexplicable counterorder: 'Don't imitate me!' (which really means, do not appropriate $m y$ object). This second command fills man with despair and turns him into the slave of an involuntary tyrant."); cf. id. at 178 (comparing the mimetic double bind to the Freudian expectation to both model oneself after one's father and refrain from doing those things that are solely within the province of the father). For Radin, it refers to social demands that women both prostitute themselves in order to gain some economic autonomy over their bodies (and thus be more equal with men) and shun prostitution as an ugly commodification of the sacred (because their bodies are different and special). See Radin, supra note 126, at 1700.

${ }^{138}$ GIRARD, supra note 20, at 149.

${ }^{139}$ See Kalyani Robbins, No-Drop Prosecution of Domestic Violence: Just Good Policy, or Equal Protection Mandate?, 52 STAN. L. REV. 205 (1999) (discussing of the efficacy of so-called no-drop prosecution policies and an equal-protection argument for their adoption).

${ }^{140} 864$ F.2d 1026 (3d Cir. 1988).

141922 F.2d 1097 (3d Cir. 1990). For a discussion of Brown and Hynson, see supra text accompanying notes $33-38$. 
formally neutral toward gender was a significant first step in accomplishing practical legal feminist goals, the logical next step, as Ginsburg implies, is extending that neutrality to those laws that are discriminatory in more insidious ways. ${ }^{142}$ Among these are legal structures that wield in oppressive ways the authority granted to government to resolve social problems, namely, structures that preserve the private sphere. The model suggests, then, that society should purge laws treating crimes and wrongs that occur in private as private matters. It should further enact laws, in the criminal and tort fields, that set private wrongs on an equal footing with public wrongs. That an act of violence plays out between a husband and wife and within the walls of a house doesn't make the act any less damaging to the public.

\section{CONCLUSION}

Despite advances from the days of chastisement, society continues to treat domestic violence as something different, and more private, than other forms of violence. Application of Girard's theory of ritual violence is one way of explaining the philosophy behind this maneuver: society channels violence into an orderly container, in this case the private sphere, on the premise that the sacrifice will stave off chaotic public violence. Yet the Girardian model also provides tools feminist legal theorists may use to overcome the poor outcomes the domestic-violence-maintaining private realm affords women. Society's reliance on Girard's framework as a justification is inherently faulty because privatizing violence is not an effective measure for preventing public violence in a modern social order. The current task is for social and legal reformers to prevent women from becoming scapegoats, to alleviate the dominating effects of rampant violence, and to restrain those features of the legal system that effectuate the private sphere while emphasizing those that treat violence as a universal problem. The problem of domestic violence, which society has conceived of as a private matter, will have to get public.

${ }^{142}$ See Ginsburg \& Flagg, supra note 124, at 18 ("Once the law books have been cleared of prescriptions of the kind [the sex-discrimination plaintiffs of the 1970s] challenged, what should one strive to enact instead?"). 